\title{
Sustainable Campsite Management in Protected Areas: A Study of Long-term Ecological Changes on Campsites in the Boundary Waters Canoe Area Wilderness, Minnesota, USA
}

\author{
Authors: \\ Holly Eagleston, $\mathrm{PhD}^{*}$ \\ Virginia Tech \\ 310 W. Campus Dr. \\ Blacksburg, VA 24061 \\ hollye1@vt.edu \\ 207-595-3018 \\ Jeffrey L. Marion, $\mathrm{PhD}$ \\ Field Station Leader/Adjunct Professor \\ USDI, U.S. Geological Survey \\ Virginia Tech \\ 310 W. Campus Dr. \\ Blacksburg, VA 24061 \\ jmarion@vt.edu \\ 540-231-6603 \\ *corresponding author
}

\begin{abstract}
Managers of protected natural areas seek to protect their natural conditions while providing opportunities for recreational visitation. Camping is an essential element of backcountry and wilderness recreation for a variety of protected natural areas in the U.S. and internationally. Furthermore, overnight visitors to protected areas spend a substantial portion of their time on campsites so their behaviors determine the nature and extent of resource impacts, and the quality of their recreational experiences can be affected by campsite conditions. The U.S. Forest Service manages nearly 2000 designated campsites in the Boundary Waters Canoe Area Wilderness. This research assessed resource conditions on 81 wilderness campsites and paired undisturbed controls in 1982 and 2014 to quantify long-term ecological changes. A comprehensive array of physical, vegetative, and soil indicators were measured to identify long-term trends over 32 years of continuous campsite use.

Our findings reveal substantial changes in area of vegetation cover, exposed soil, and soil erosion on campsites. Although mean campsite size is unchanged, the proportion of campsite area in the "core" has decreased, shifting some use and impact into peripheral "satellite" tenting areas just beyond campsite borders. The ecology of campsites has been significantly altered by a large reduction in number and cover of campsite trees. The number of campsite trees decreased by $44 \%$ from 1982 to 2014 . Visitors are cutting both on- and off-site trees for firewood, and tree seedlings are rarely able to germinate and survive due to visitor activity.

These findings reveal that older campsites are not stable. Long-term camping impacts that are ecologically, managerially, and experientially meaningful are occurring; these impacts could be
\end{abstract}


minimized through more sustainable management practices. These include selecting more resistant sites, such as those with resistant rocky shorelines, and sloping terrain that constrains campsite expansion. Construction and maintenance of tenting sites can attract and spatially concentrate camping impact. Actions to halt tree cutting are also critical. Heavy long-term visitation in protected natural areas requires more sustainable and intensive visitor impact management actions.

Keywords: Recreation ecology; Sustainable recreation management; Campsite management; Longitudinal ecological change

\section{Introduction}

Most protected areas internationally are managed to preserve natural conditions, biodiversity, and natural processes, often excluding many forms of human development while accommodating recreation visitation (Leverington et al. 2010). For example, the U.S. National Wilderness Preservation System (P.L. 88-577) charges agencies to administer these protected areas: "for the use and enjoyment of the American people in such manner as will leave them unimpaired for future use and enjoyment as wilderness." In light of increasing visitation, managers must discover and implement improved visitor use management practices that minimize resource degradation. For this to occur, protected natural area managers need to better understand what visitation-related ecological changes occur over time and what factors most strongly influence the extent of change. Such knowledge can then be applied to inform the selection of management actions able to sustain intensive visitation with minimal degradation.

Environmental degradation from visitor activities can contribute to a range of resource impacts that vary by type and severity. Even low levels of trampling disturbance can reduce vegetation height, cover, and biomass (Cole 1995a; Cole1995b; Growcock \& Pickering 2011; Marion et al. 2016). Higher levels of trampling lead to more complete vegetation loss and compositional change as plants are lost or replaced by more resistant species (Cole 1995b; Marion \& Cole 1996; Smith \& Newsome 2002). Concentrated traffic also pulverizes soil leaf litter and humus layers, which are either lost through erosional processes or intermixed with underlying mineral soils. Exposed soils are more vulnerable to displacement, compaction, and erosion (Marion et al. 2016; Monti \& Mackintosh 1979). Compaction reduces soil pore space and water/air infiltration, increasing water runoff and erosion rates. Additional impacts specific to camping activities include campfire-related impacts such as tree damage, felling, and depletion of woody material (Hall \& Farrell 2001; Reid \& Marion 2005; Smith \& Newsome 2002).

This study examines long-term resource impacts on agency-designated campsites in a U.S. wilderness area. Two management strategies applied to minimize camping impacts include dispersal, where campers select a pristine site with durable substrates or vegetation, or containment - where campers concentrate their activity on a limited number of small, resistant, well-established or designated campsites (Hammitt et al. 2014; Marion 2016). Research and management experience have found the containment strategy to be most effective in moderate to high use areas (Leung \& Marion 1999; Marion 2016; Reid \& Marion 2004). Due to increasing visitation, managers are funding studies like this one to investigate long-term impacts and improve guidance on campsite sustainability: which we define as the ability of campsites to accommodate intensive long-term use while remaining in good condition, with minimal maintenance or restoration. Research questions include: 1) How do campsite conditions change over several decades of continual use, 2) What use-related, environmental, and managerial factors most 
strongly influence long-term campsite conditions, and 3) What are the implications of these findings for improving the sustainability of campsite management?

In this study, we seek to answer these questions by analyzing data collected in 1982 and 2014 on a large sample of designated campsites in the Boundary Waters Canoe Area Wilderness (BWCAW) in northern Minnesota. Specifically, we replicate an array of biophysical measurements on 81 BWCAW campsites and paired control sites to document and analyze 32 years of ecological change (Marion 1984; Marion and Merriam 1985a; Marion and Merriam 1985b).

\section{Longitudinal campsite studies}

The BWCAW has served as an important study area for some of the earliest recreation ecology research, particularly for longitudinal studies. A study examining the effect of differing use levels on impacts found that even light use ( 0 to 30 days use/season) resulted in substantial loss of ground cover (Frissell \& Duncan 1965). A 1969 study by McCool, Merriam and Cushwa found that campsites on islands and along main canoe routes showed more substantial impacts, which they attributed primarily to higher use levels. Merriam and others (1973) also reported that campsites are most highly affected by initial site use. Once an area is selected as a campsite, trampling quickly results in loss of organic and vegetative ground cover, while subsequent traffic results in diminishing per capita impact (Merriam \& Smith 1974). However, some impacts do increase over time and with increasing use levels, notably exposed soil. Some of this early work was continued by Merriam \& Peterson (1983), who examined changes on eight BWCAW campsites over 15 years, finding that higher use sites expanded in size over time and that visitors were continuing to cut trees for firewood (Merriam \& Peterson 1983).

Elsewhere, Cole and his co-investigators have reported results from several long-term studies employing rapid monitoring-level ratings (Cole 2013, Cole \& Parsons 2013, Cole et al. 2008). Monitoring of Grand Canyon National Park backcountry campsites over 20 years found campsite sizes to be stable (Cole et al. 2008). While high-use sites were more degraded than low-use sites, within each use level resource impacts were relatively consistent over time.

We note that none of these early BWCAW and later long-term monitoring studies included detailed ecological measurements of both campsite and paired "control" site conditions replicated over time. There are several important limitations to these studies. First, plant communities vary with respect to plant cover and other attributes. Analyses designed to examine sustainability are most valid when they compare "absolute difference" values, computed by subtracting campsite indicator values from values assessed on adjacent environmentally paired undisturbed "control" areas. Second, these early studies and nearly all monitoring programs do not count tree damage and felling indicators both onsite and offsite and report them as density (\#/ha) measures. Longitudinal comparisons for these indicators become less valid over time as campsite sizes change, and as campsite trees are cut down the number of damaged and felled trees reported in subsequent monitoring cycles must inevitably decline, indicating improving conditions when the opposite is true. Third, monitoring studies generally employ rapidly assessed ratings rather than accurate measurements. Ratings are a coarse approximation of actual change, particularly when large percentages of sites fall within a single rating category, or when substantial degradation occurs to sites in the "worst" category, which is open-ended (e.g. campsite size $>300 \mathrm{~m}^{2}$ ). 
We found no other studies that avoided these limitations, which we've addressed in this research. In 2014 we returned to reassess ecological changes on BWCAW campsites and paired control sites first measured in 1982 (Marion 1984, Marion \& Merriam 1985a; Marion \& Merriam 1985b). It provides a comprehensive dataset with longitudinal biophysical measurements and a larger sample size needed to improve understanding of long-term ecological changes and their implications for sustainable campsite management.

\section{Campsite sustainability}

A number of factors identified in the 1982 study relate to campsite sustainability and are reviewed here. While vegetative ground cover declined from an average of $94 \%$ offsite to $36 \%$ onsite, the amount and durability of vegetation cover increased significantly with increasing campsite sunlight exposure (Marion \& Merriam 1985a). Shade-tolerant plants are particularly susceptible to trampling while sunloving plants, primarily grasses and sedges (graminoids), are more trampling-resistant. For example, mean dense vegetation ground cover was only $4 \%$ on campsites with $75-100 \%$ tree cover, but increased to $52 \%$ on campsites with less than $25 \%$ tree cover (Marion \& Merriam 1985a). Over time, trampling alters campsite plant composition as fragile plants are replaced by trampling-resistant, often non-native, species (Marion \& Merriam 1985a). Regression modeling found that soil compaction can be minimized by selecting sites in areas with thick organic soil horizons, which reduce compactive forces and intermix with underlying mineral soils (Marion \& Merriam 1985b).

A BWCAW campsite restoration, rehabilitation, and maintenance program seeks to enhance the sustainability of campsites kept open to use (Marion \& Sober 1987). Actions that enhance campsite sustainability include a designated camping policy that restricts camping to a limited number of durable sites, visitor entry point quotas to match visitor numbers to site numbers, group size restrictions to limit campsite expansion, and site management actions like tent site creation and canoe landing closure and rehabilitation to concentrate visitor activity, minimize soil loss, and shrink site size. Cole (1992) noted that the spatial concentration of visitor activity on campsites enhances sustainability by increasing the proportion of time spent in the central part of the campsite, reducing trampling to peripheral areas. Campsite research at Isle Royale National Park found that constructing side-hill campsites in sloping terrain was highly effective in limiting the areal extent of camping impact (Marion \& Farrell 2002).

\section{Study Area}

The U.S. Forest Service (USFS) restricts the majority of BWCAW camping to designated campsites, so maintaining their natural conditions and limiting resource impacts over time are core management objectives. The management of campsites able to sustain high use while keeping associated resource impacts within acceptable limits is extremely challenging given the area's strong resource protection mandate and high visitation.

The Boundary Waters Canoe Area Wilderness (BWCAW) is a 441,107-ha wilderness area in northeastern Minnesota, administered by the U.S. Forest Service, Superior National Forest. Designated as wilderness by the 1964 Wilderness Act, it has long been one of the most visited wilderness areas, with approximately 150,000 overnight and day-use visitors annually (averaged from 2009-2014 data), unchanged from 1982. With over 1000 interconnected lakes and streams, the area's primary recreational activities include canoeing and fishing. Visitors must obtain wilderness permits from May thru 
September and group sizes are limited to 9 (10 in 1982). Most of the area is designated as nonmotorized. The Forest Service currently provides 1,957 designated campsites in the area, most of which have a shoreline boat landing, primitive pit toilet, and steel fire grate. A travel zone-based permitting system matches the distribution of visitors and campsites.

The soils in the area are derived from glacial deposits, covering a thin mantle of glacial-till and lacustrine sediments (Prettyman 1987). The area receives between 66 and $78 \mathrm{~cm}$ of precipitation per year, with $40 \%$ falling as snow. The average summer and winter temperatures are $20^{\circ} \mathrm{C}$ and $-11^{\circ} \mathrm{C}$, respectively. The area's lakes are interspersed with northern boreal hardwood-conifer forests comprised of pines, fir, spruce, cedar, and hardwoods (Moyle \& Moyle 1977).

\section{Methods}

This study replicates Marion's 1982 doctoral study of 96 wilderness campsites and controls (Marion 1984). A stratified random sample was employed with sites equally distributed among three use levels and five ecological land types. An effort was made to relocate and measure the same sites in the 2014 study. Sites were omitted if found to be severely affected by wildfire or wind-throw, or had been closed. Eighty-one sites were remeasured in 2014 using the 1982 protocols and several new indicators. For each campsite, a circular control plot of $50 \mathrm{~m}^{2}$ (size determined by a species-area curve, nested-plot technique) was also assessed in an adjacent undisturbed area with similar vegetation (Figure 1). Control plots were environmentally similar to their paired campsites (e.g., same ecological land type, substrates, slope, aspect, and distance to water).

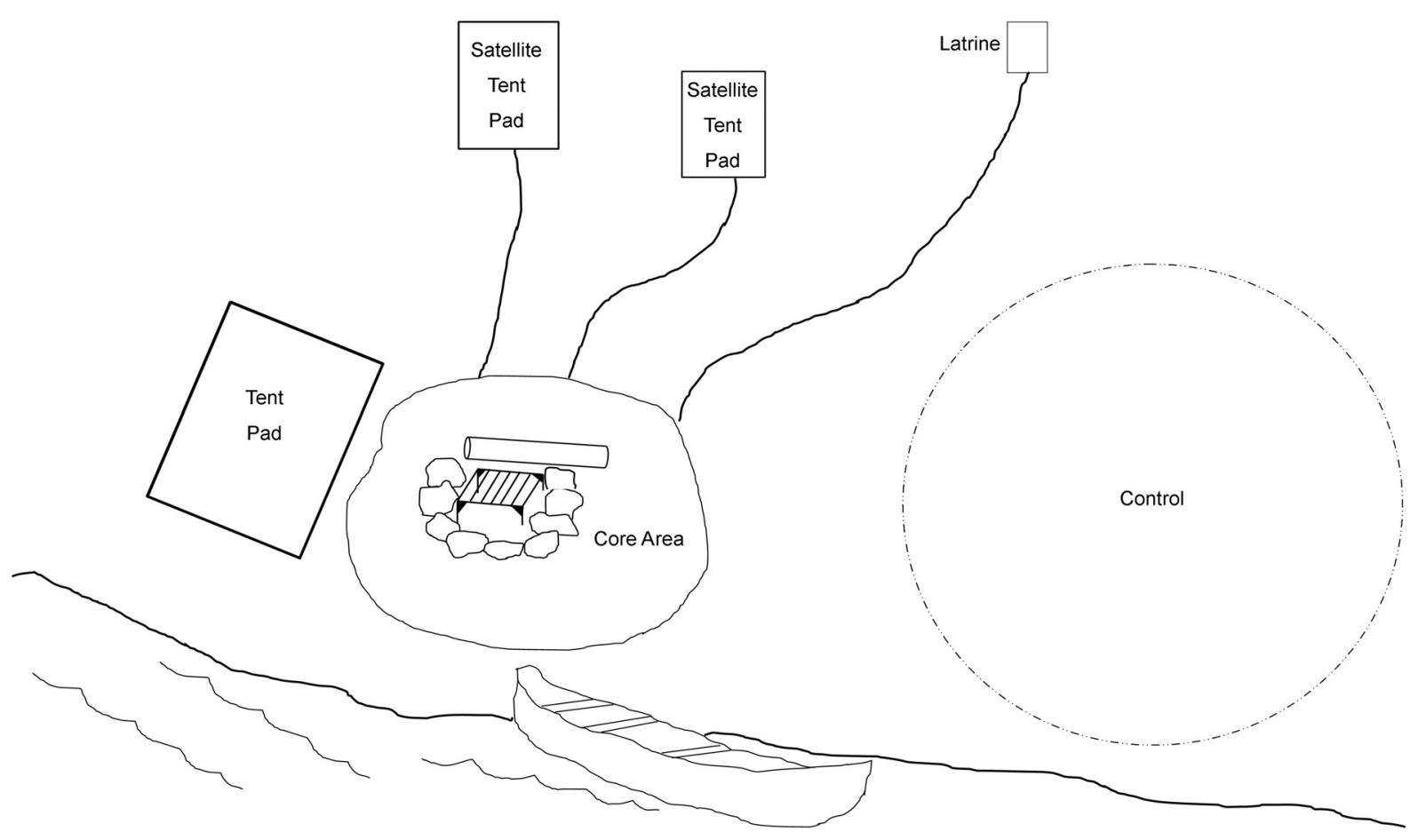

Figure 1. Layout of a typical campsite (not to scale) with a shoreline canoe landing area, core area with a steel fire grate, adjacent tent pad and a trail to the latrine. The $50 \mathrm{~m}^{2}$ control is shown next to the campsite in an adjacent undisturbed area. 
Campsites typically consisted of a core area around a fire grate placed by USFS, a tent pad, and a trail to the latrine, some also included user-created tent pads away from the main site (Figure 1). Campsite size was measured within boundaries defined by pronounced changes in ground vegetation height, composition, or cover, excluding any undisturbed "islands" of vegetation and including adjacent off-site visitor-created "satellite" tenting areas. The number and area of satellite sites and shoreline boat landings were recorded. Campsite soil loss was estimated in 2014 by measuring the average depth of soil loss on the core site, access trail, and landing area separately and multiplying by the size of each area. Soil loss was evaluated by examining soil loss around tree roots, with comparisons to reference trees of the same species in undisturbed offsite areas. We also examined soil levels around embedded rocks and bedrock depicted in the 1982 photos and at shorelines we were able to extrapolate soil heights from adjacent undisturbed areas.

Six categories of mutually exclusive ground cover were assessed as percentages of the campsite or control area: 1) dense vegetation cover - areas with 51-100 non-woody plant cover less than $0.5 \mathrm{~m}$ tall, 2) sparse vegetation cover - areas with 5-50\% plant cover, 3) exposed rock, 4) exposed root area - areas where tree roots are moderately to severely exposed, 5) exposed soil - areas where soil is largely exposed with $<5 \%$ litter or vegetation cover, and 6) litter cover - areas covered by organic litter and less than $5 \%$ plant cover. Sparse and dense vegetation cover is sometimes combined as "vegetation cover." Areal measures of vegetation loss and exposed soil were calculated by multiplying percent cover estimates by campsite size. Separate cover estimates were also made for trees, shrubs, herbs, mosses and lichen, and for each plant species relative to the total campsite or control area.

For campsites, the number of living trees, seedlings, and stumps were counted and divided by campsite size to obtain standardized per hectare values. At each site and control, a 4-class ordinal scale rating was used to determine site expansion potential based on constricting topography and vegetation surrounding the campsite. Sites with high expansion potential are surrounded by flat terrain and sparse vegetation, while steeper terrain and dense vegetation contribute to a low expansion potential rating. To evaluate the efficacy of this expansion rating we analyzed change in campsite size from 1982 to 2014.

Campsite use estimates were acquired from a U.S. Forest Service computerized travel model and knowledgeable wilderness managers in 1982 and 2014 (Marion and Merriam 1985a). Campsites were divided into the same discontinuous level of use groupings used in the 1982 study: 1) low use $(<12$ nights/yr), 2) moderate use (20-40 nights/yr), and 3) high use (>60 nights/yr). Campsites with intermediate use estimates (e.g., 12-19, or 41-60 nights/yr) were not assessed in 1982, and were not used in use level analyses in 2014. Other characteristics included campsite age (retrieved from USFS records), site maintenance (e.g., tent pad improvement or ruination, shoreline rock work), and site closure. Campsite photos taken in 1982 were replicated in 2014.

The 1982 and 2014 data were analyzed with paired t-tests using SAS JMP software; data were normally distributed following transformations and removal of outliers. Campsite and control measurements from both years were analyzed separately to evaluate temporal changes. Absolute difference values were also computed by subtracting control values from their paired campsites, with paired t-tests to examine camping impacts to vegetation and soil attributes. The Kruskal-Wallis rank sum test was applied to investigate the influence of level of use and site expansion rating; this non-parametric test was used due to variable or small sample sizes, or violation of the normality assumption. 


\section{Results}

Change in campsite conditions

From 1982 to 2014 the aggregate area of camping disturbance declined by $6.8 \%$, though this change was not statistically significant $(\mathrm{p}$-value $=.150)$. However, campsite core areas significantly diminished in size an average of $31 \mathrm{~m}^{2}$, while the areas of adjacent off-site satellite tenting areas increased significantly by $18 \mathrm{~m}^{2}$ (Table 1$)$.

Table 1. Changes in the mean sizes of campsite core and satellite areas from 1982 to 2014.

\begin{tabular}{|c|c|c|c|c|c|c|c|}
\hline \multirow{2}{*}{ Campsite Size } & \multirow{2}{*}{$\begin{array}{c}\text { Mean } \\
1982 \\
\left(\mathrm{~m}^{2}\right)\end{array}$} & \multirow{2}{*}{$\begin{array}{c}\text { Mean } \\
2014 \\
\left(\mathrm{~m}^{2}\right)\end{array}$} & \multirow{2}{*}{$\begin{array}{c}\text { Mean } \\
\text { Diff. } \\
1982- \\
2014\left(\mathrm{~m}^{2}\right)\end{array}$} & \multirow{2}{*}{$\begin{array}{c}\text { P. } \\
\text { value }^{a}\end{array}$} & \multicolumn{3}{|c|}{$\begin{array}{l}\text { Aggregate Measures } \\
\left(\mathrm{m}^{2}\right)\end{array}$} \\
\hline & & & & & 1982 & 2014 & Diff. \\
\hline Core $(n=74)$ & 191 & 175 & $-16(75)^{b}$ & .006 & 17,351 & 12,798 & $\begin{array}{c}- \\
2,274\end{array}$ \\
\hline Satellite $(n=75)$ & 10 & 28 & $18(27)$ & $<.001$ & 802 & 2,149 & 1,335 \\
\hline Total $(n=75)$ & 201 & 203 & $2(81)$ & .150 & 16,569 & 15,447 & $\begin{array}{c}- \\
1,121\end{array}$ \\
\hline
\end{tabular}

${ }^{a}$ Paired t-test, $\mathrm{N}$ distribution; ${ }^{\mathrm{b}}$ Standard Deviations.

The USFS has sought to discourage use of the satellite tenting areas by placing woody materials on them and providing 3-5 good tent pads within the core campsite area (though low staffing limits this work). The mean number of tent pads per site in 1982 was 4.0, with an average of .56 satellite sites. In 2014, the mean number of tent pads was 4.4 with 1.4 satellite sites per campsite. While the number of tent pads increased by $10 \%$ (ns, p $>.05)$, the number of satellite sites more than doubled $(\mathrm{p}<.001)$.

Table 2. Effectiveness of campsite expansion ratings applied to campsites in 1982 evaluated by median changes in campsite size (2014 - 1982 values) over 32 years.

\begin{tabular}{|c|c|c|c|c|c|c|}
\hline \multirow[b]{2}{*}{ Campsite Size } & \multicolumn{4}{|c|}{ Campsite Expansion Potential } & \multirow{2}{*}{$\begin{array}{c}\text { H- } \\
\text { value }^{a}\end{array}$} & \multirow{2}{*}{$\begin{array}{c}\text { P- } \\
\text { value }\end{array}$} \\
\hline & $\begin{array}{l}\text { High } \\
(n=8)\end{array}$ & $\begin{array}{l}\text { Moderate } \\
(n=42)\end{array}$ & $\begin{array}{c}\text { Poor } \\
(n=24)\end{array}$ & $\begin{array}{c}\text { Very Poor } \\
\quad(n=7)\end{array}$ & & \\
\hline Core $\left(\mathrm{m}^{2}\right)$ & -14 & -26 & -30 & -69 & 3.24 & .356 \\
\hline Satellite $\left(\mathrm{m}^{2}\right)$ & 68 & 36 & 37 & 23 & 1.0 & .149 \\
\hline Total $\left(m^{2}\right)$ & 16 & 0.2 & 2 & -60 & 1.9 & .122 \\
\hline
\end{tabular}

${ }^{\mathrm{a}}$ Kruskal-Wallis rank sum test

In the original selection of designated campsites, USFS managers often adopted existing visitor-created sites. Over time staff have closed campsites on small islands and in areas that had insufficient soil to support pit toilets, replacing them when possible with less erodible sites that had bedrock shorelines. A recommendation from Marion (1984) was to consider shifting use to campsites whose expansion would be constrained by sloping topography, rockiness, wet soils, or dense woody vegetation. A campsite expansion potential rating based on these attributes was applied in 1982 (Table 2). A very poor rating 
reflects a campsite that should resist expansion due to these attributes while campsites with a high rating could be more easily expanded. We evaluated the predictive efficacy of this rating by subtracting 1982 from 2014 areal measures for the core, satellite, and total campsite areas for each rating. While the changes in these areal measures across ratings do indicate predictive success, variability and small sample sizes for the high and very poor ratings prevent statistically significant differences $(\mathrm{p}>.05)$.

\section{Change in forest structure}

Forest structure both on and off BWCAW campsites has changed substantially in the three decades since the 1982 study. The forests are more mature in 2014, with greater tree canopy cover and density, resulting in less herb and grass cover and greater moss cover in control areas (Table 3). In contrast, the campsites lost trees and tree cover and gained ground vegetation over 32 years. All components of the forest structure are significantly altered on campsites in 2014 based on paired comparisons to control values. The most substantial change is shrub cover, reduced $42.1 \%$ on campsites, followed by reductions in tree cover (28.7\%) and moss cover (19.5\%) (Table 3). Due to the high density of woody vegetation in control areas and greater sunlight on campsites, the amount of herbaceous and grass cover on campsites is $14.5 \%$ greater than on controls.

Table 3. Changes in tree, shrub, herb/grass, and moss cover on campsites and controls from 1982 to $2014(\mathrm{~N}=76)$.

\begin{tabular}{|l|c|c|c|c|c|c|}
\hline \multirow{2}{*}{ Indicator } & \multicolumn{3}{|c|}{ Change: 1982 to 2014 } & \multicolumn{2}{c|}{ Change: 2014 } \\
\cline { 2 - 7 } & Camp - Camp & \multicolumn{2}{c|}{ Control - Control } & \multicolumn{2}{c|}{ Camp - Control } \\
\cline { 2 - 7 } & Mean & $\begin{array}{c}\text { P- } \\
\text { value }\end{array}$ & Mean & $\begin{array}{c}\text { P- } \\
\text { value }\end{array}$ & Mean & $\begin{array}{c}\text { P- } \\
\text { value }\end{array}$ \\
\hline Trees (\%) & $-10.5(34.7)^{\mathrm{a}}$ & .001 & $6.3(27.7)$ & .044 & $\begin{array}{c}-28.7 \\
(30.1)\end{array}$ & $<.001$ \\
\hline Shrubs (\%) & $-3.9(9.7)$ & $<.001$ & $0.8(47.1)$ & .876 & $\begin{array}{c}-42.1 \\
(34.8)\end{array}$ & $<.001$ \\
\hline $\begin{array}{l}\text { Herb/Grass } \\
(\%)\end{array}$ & $10.3(39.4)$ & .004 & $\begin{array}{c}-42.8 \\
(36.1)\end{array}$ & $<.001$ & $\begin{array}{c}14.5 \\
(35.7)\end{array}$ & $<.001$ \\
\hline Moss (\%) & $0.2(7.4)$ & .859 & $11.6(11.8)$ & $<.001$ & $\begin{array}{c}-19.5 \\
(26.5)\end{array}$ & $<.001$ \\
\hline
\end{tabular}

a Standard Deviation; ${ }^{\mathrm{b}}$ Absolute Difference values, 2014 data.

The number and density of trees on campsites has significantly declined over the 32-year study period. On the 81 campsites studied, an average of 64.6 trees per hectare have been lost from 1982 to 2014 (Table 4). We attribute this substantial tree loss to a combination of factors: felling by visitors for firewood, mortality from tree damage, root exposure, and natural causes (drought, insects, disease, fire, and lightning), and hazardous tree removal. Within campsite boundaries 384 tree stumps were counted in 2014; an additional 1054 stumps were counted in adjacent offsite areas. While the average number of stumps on the campsite proper did not change from 1982 to 2014, additional offsite stumps were found indicating that visitors are searching farther off camp to harvest firewood. A substantial majority of these offsite stumps were $<15 \mathrm{~cm}$ diameter, indicating they were in fact harvested by visitors for firewood, as opposed to removal as hazardous trees. Tree cutting has led to a significant decrease in the 
number of trees on and around campsites, reducing tree canopy cover and increasing the amount of sunlight reaching the ground (Figure 2). A significant number of tree seedlings have also been lost. In addition, due to visitor trampling and cutting, tree seedlings are rarely able to establish, grow, and reach maturity on campsites, suggesting that the historical deforestation of campsites will continue.

1982

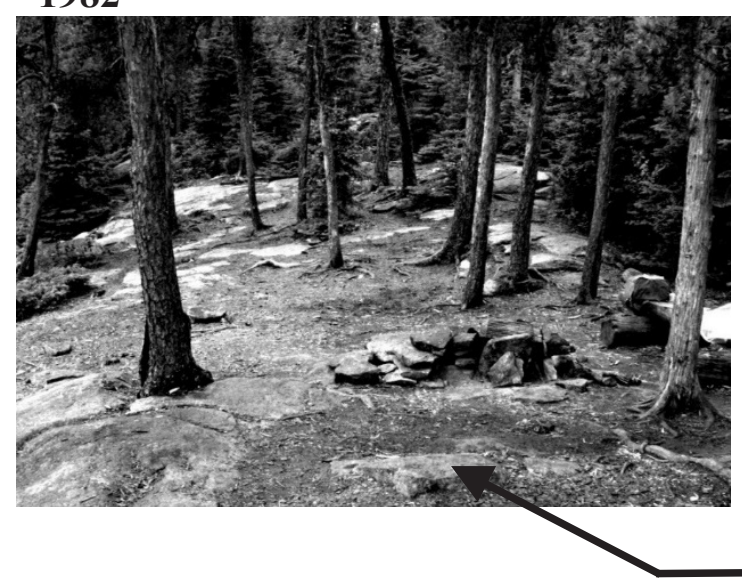

2014

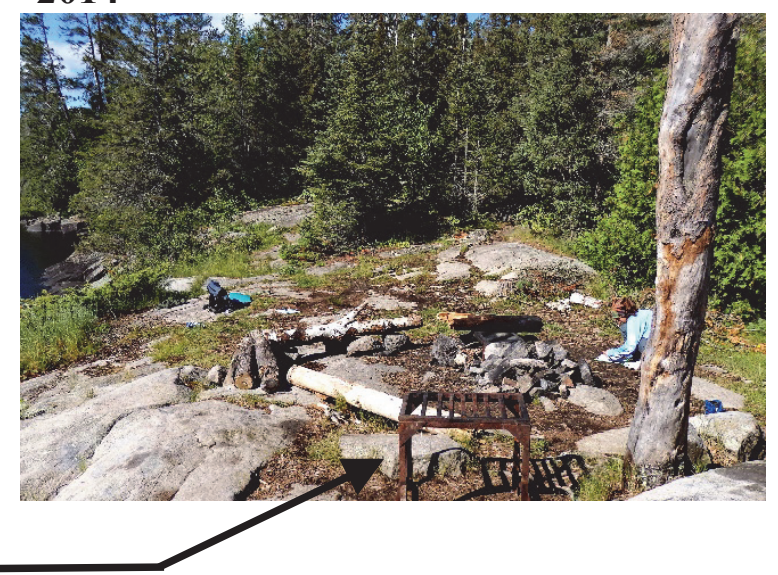

Figure 2. Photo comparison of tree loss and groundcover changes over 32 years on a representative campsite.

Table 4. Change in the number of trees, tree seedlings, and stumps per hectare on campsites from 1982 to 2014.

\begin{tabular}{|l|c|c|}
\hline \multirow{2}{*}{ Indicator } & \multicolumn{2}{|c|}{$\begin{array}{c}\text { Change: } 1982 \text { to } \\
\text { 2014 }\end{array}$} \\
\cline { 2 - 3 } & \multicolumn{2}{|c|}{ Camp - Camp } \\
\cline { 2 - 3 } & Mean & $\begin{array}{c}\text { P- } \\
\text { value }\end{array}$ \\
\hline Trees/ha ( $n=78)$ & $\begin{array}{c}-64.6 \\
(303.5)^{\mathrm{a}}\end{array}$ & .031 \\
\hline $\begin{array}{l}\text { Seedlings/ha } \\
(\mathrm{n}=75)\end{array}$ & $\begin{array}{c}-50.9 \\
(152.8)\end{array}$ & .002 \\
\hline $\begin{array}{l}\text { Stumps/ha } \\
(\mathrm{n}=79)\end{array}$ & $-1.7(190.6)$ & .467 \\
\hline
\end{tabular}

a Standard Deviation.

\section{Change in groundcover}

The loss of vegetation cover and exposure of soil are other important components of impact from recreational traffic and camping activities. Table 5 characterizes percent and areal measures for these indicators by subtracting 1982 values from 2014 values for campsites and controls separately to reveal changes over the 32 years. Exposed soil increased significantly on campsites $\left(8.2 \%, 16.8 \mathrm{~m}^{2}\right)$, with a slight $0.3 \%$ increase in control areas. Vegetation cover also increased significantly on campsites $(16.3 \%$, $62 \mathrm{~m}^{2}$ ), while vegetation cover in control areas decreased an average of $18.3 \%$. Based on absolute difference values in 2014 , vegetation cover on campsites is $22.6 \%$ higher than in paired control areas, and exposed soil is $18.3 \%$ higher (Table 5 ). 
Table 5. Changes in exposed soil and ground vegetation cover on campsites and controls from 1982 to $2014(\mathrm{~N}=76)$.

\begin{tabular}{|l|c|c|c|c|c|c|}
\hline \multirow{2}{*}{ Indicator } & \multicolumn{3}{|c|}{ Change: 1982 to 2014 } & \multicolumn{2}{c|}{ Change: 2014 } \\
\cline { 2 - 7 } & \multicolumn{2}{|c|}{ Camp - Camp } & \multicolumn{2}{c|}{ Control - Control } & \multicolumn{2}{c|}{ Camp - Control } \\
\cline { 2 - 7 } & Mean & $\begin{array}{c}\text { P- } \\
\text { value }\end{array}$ & Mean & $\begin{array}{c}\text { P- } \\
\text { value }\end{array}$ & Mean & P-value \\
\hline Exposed Soil (\%) & $8.2(14)^{\mathrm{a}}$ & $<.001$ & $.3(1.4)$ & .047 & $18.3(15.1)$ & $<.001$ \\
\hline Exposed Soil $\left(\mathrm{m}^{2}\right)$ & $16.8(38)$ & $<.001$ & $1.6(6.8)$ & .047 & $\mathrm{~N} / \mathrm{A}$ & $\mathrm{N} / \mathrm{A}$ \\
\hline $\begin{array}{l}\text { Vegetation Cover } \\
(\%)\end{array}$ & $16.3(27)$ & $<.001$ & $\begin{array}{c}-18.3 \\
(24.2)\end{array}$ & $<.001$ & $22.6(33.7)$ & $<.001$ \\
\hline $\begin{array}{l}\text { Vegetation Cover } \\
\left(\mathrm{m}^{2}\right)\end{array}$ & $62.0(103)$ & $<.001$ & $-9.2(28.7)$ & $<.001$ & $\mathrm{~N} / \mathrm{A}$ & $\mathrm{N} / \mathrm{A}$ \\
\hline
\end{tabular}

${ }^{a}$ Standard Deviation; ${ }^{b}$ Absolute Difference values, 2014 data.

Figure 3 presents mean groundcover changes on campsites from 1982 to 2014. Dense and sparse vegetation cover both increased substantially, equivalent to an equal reduction in the percent cover of organic litter. This is consistent with photo evidence of long-term trends, illustrated in the Figure 1 photos. Most campsites have been in use for more than five decades and many campsite trees have been lost without replacement. Tree loss and the associated increased sunlight are favoring trampling-resistant but shade-intolerant grass and sedge cover in the less trafficked peripheral campsite areas. For example, campsites in 2014 have $41.7 \%$ graminoid cover, compared to $3.2 \%$ in neighboring control areas, which generally have dense tree canopies. Herbaceous cover of forbs is $6.6 \%$ on campsites versus $29.2 \%$ in control areas. 


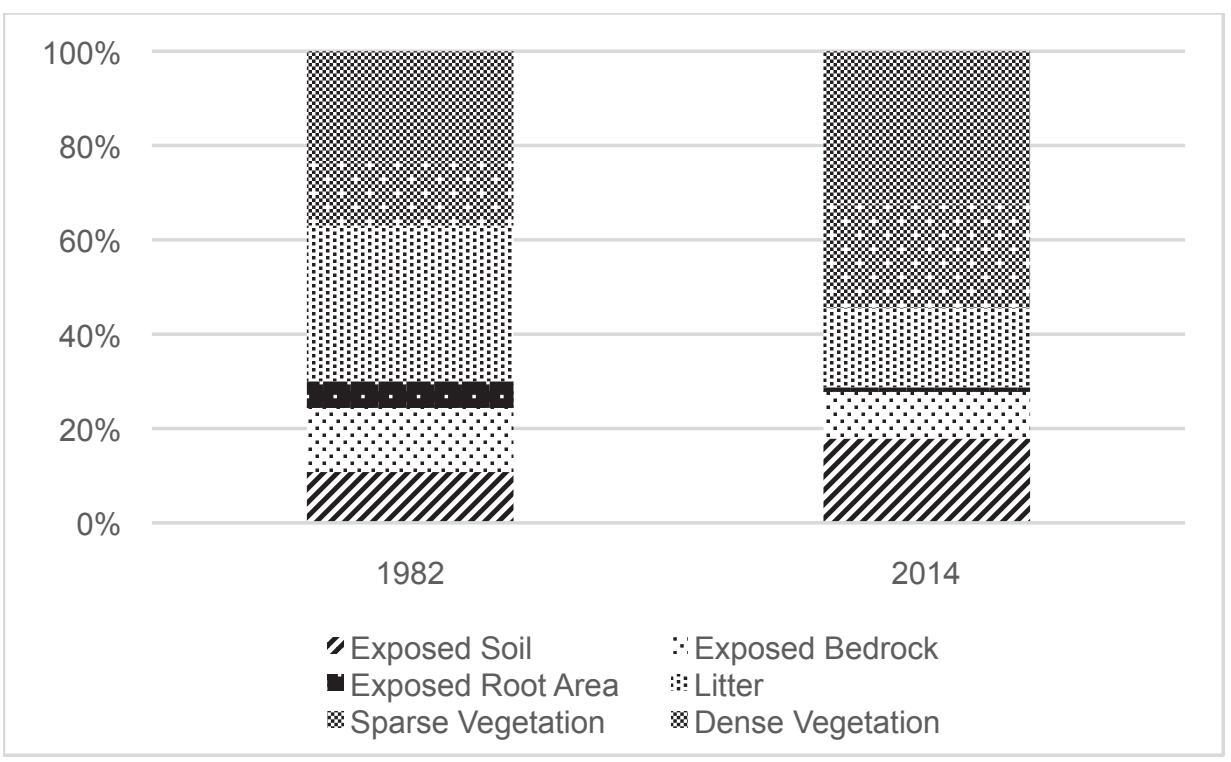

Figure 3. Groundcover changes on campsites from 1982 to 2014.

Once vegetation and organic litter cover are removed from campsites, their underlying organic and mineral soil are exposed and subject to wind and water erosion and loss. Soil loss is perhaps the most important long-term form of campsite degradation because soil creation requires many centuries. Soil loss was estimated only in 2014 (Table 6). Mean aggregate campsite soil loss is $17.2 \mathrm{~m}^{3}$, with the majority occurring on the campsite core due to its large size. Mean incision values were greatest in boat landing areas $(24 \mathrm{~cm})$, where protective vegetation cover is often removed by foot traffic and boats. Exposed soils in these shoreline areas are susceptible to loss from rain, and to wave action caused by wind and motorboats. Satellite tenting areas did not exhibit soil loss as these areas are fairly flat and receive substantially less foot traffic. When mean soil loss per campsite is extrapolated to the 1,957 BWCAW campsites, an aggregate estimated $33,660 \mathrm{~m}^{3}$ of soil has been lost due to camping activities.

Table 6. Estimated campsite soil loss, 2014 data.

\begin{tabular}{|l|c|c|}
\hline $\begin{array}{c}\text { Campsite } \\
\text { Component }\end{array}$ & $\begin{array}{c}\text { Mean } \\
\text { Incision } \\
\text { Depth }(\mathbf{c m})\end{array}$ & $\begin{array}{c}\text { Mean Soil } \\
\text { Loss }\left(\mathbf{m}^{\mathbf{3}}\right)\end{array}$ \\
\hline Trails $(\mathrm{n}=35)$ & 9 & 0.9 \\
\hline $\begin{array}{l}\text { Boat Landings } \\
(\mathrm{n}=70)\end{array}$ & 24 & 4.9 \\
\hline $\begin{array}{l}\text { Campsite Core } \\
(\mathrm{n}=80)\end{array}$ & 6 & 11.4 \\
\hline Total $(\mathrm{n}=80)$ & 7 & 17.2 \\
\hline
\end{tabular}

Table 7. Relative changes in resource conditions on campsites from 1982 to 2014 as influenced by level of use.

\begin{tabular}{|c|c|c|c|c|c|}
\hline Indicator & $\begin{array}{c}\text { Low Use } \\
(\mathrm{N}=6)\end{array}$ & $\begin{array}{c}\text { Medium Use } \\
(\mathrm{N}=25)\end{array}$ & $\begin{array}{c}\text { High Use } \\
(\mathrm{N}=27)\end{array}$ & H-value ${ }^{\mathrm{a}}$ & P-value \\
\hline
\end{tabular}




\begin{tabular}{|c|c|c|c|c|c|}
\hline Vegetation Cover & \multicolumn{3}{|c|}{ Median Values } & \\
\hline Tree (\%) & 0 & -22.5 & -22.5 & 3.58 & .167 \\
\hline Shrub (\%) & -7.5 & -1 & -1 & 4.87 & .087 \\
\hline Herb/Grass (\%) & 0 & 0 & 0 & 1.59 & .450 \\
\hline Moss (\%) & 0 & 0 & -1 & 0.91 & .633 \\
\hline Ground Cover & & & & & \\
\hline Exposed Soil (m ${ }^{2}$ ) & 3.2 & 9.5 & 31.7 & 2.94 & .229 \\
\hline Campsite Metrics & & & & & \\
\hline Core Campsite Size & -2.1 & -3.1 & -59.5 & 4.14 & .126 \\
\hline Satellite Size (m ${ }^{2}$ ) & 0 & 16.7 & 34.7 & 3.38 & .184 \\
\hline Landings (\#/site) & 1 & 1 & 2 & 1.16 & .322 \\
\hline Satellite (\#/site) & 0 & 1 & 1 & 4.48 & .106 \\
\hline Erosion & & & & & \\
\hline Total Soil loss (m $\left.{ }^{3}\right)^{a}$ & 4.2 & 11.0 & 22.6 & 14.66 & $<.001$ \\
\hline Exposed Roots (\%) & 0 & -2 & -6 & 11.99 & .002 \\
\hline
\end{tabular}

${ }^{a}$ Measured only in 2014; ${ }^{a}$ Kruskal-Wallis rank sum test

\section{Influence of use level}

The relative differences in resource conditions for campsites at low, moderate, and high use are presented in Table 7. Note that the reported values were computed by subtracting 2014 campsite values from 1982 campsite values, with no comparison to their controls. An exception was campsite soil loss, which was only measured in 2014. This measure and the percentage of trees with exposed roots were the only two indicators found to be statistically significant. Low use sites lost significantly less soil and had fewer trees with exposed roots than the high use sites. While there does appear to be a relationship between level of use and the areal measures (campsite size and soil exposure), data variability prevented statistical significance.

\section{Discussion}

In this section we review the findings relative to our first two research questions: 1) How do campsite conditions change over several decades of continual use, 2) What use-related, environmental, and managerial factors most strongly influence long-term campsite conditions. This longitudinal study addressed significant limitations in prior studies by employing accurate measurements of campingrelated ecological change on 81 campsites and paired environmentally-similar control areas assessed in 1982 and 2014. This research design enabled comparisons and statistical testing of longitudinal change on campsites and controls separately, and on campsite/control absolute difference values.

\section{Area of Disturbance}

Land managers generally seek to limit aggregate recreation-related resource impact by minimizing the impact "footprint" - for example, restricting the number and areal extent of trails, recreation sites, and campsites (Leung \& Marion 1999; Leung \& Marion 2004). BWCAW managers employ a "containment" strategy for minimizing camping impact by limiting camping to designated sites and restricting their number. Our findings support this strategy; the aggregate area of camping impact (campsite numbers 
and mean size) has remained relatively unchanged over 32 years, and we saw no evidence of illegal camping. Stable campsite sizes in the BWCAW area appear consistent with findings in Grand Canyon National Park, where researchers also found campsite sizes to remain stable over time (Cole et al. 2008).

However, our data do show a spatial shift in visitor use of the campsites, with a doubling in the number of adjacent off-site satellite tenting areas. This shift could be influenced by several factors: 1) decreased tenting opportunities within core site areas due to soil loss that exposes rocks and roots (observed), 2) an increase in group use and associated need for more tenting locations, 3) a shift from large to smaller and more numerous tents (observed), and 4) a shift in visitor preferences to seek shade from the sun, privacy/solitude, and natural quiet (distance from those who talk or snore). Previous studies have not documented or commented on these types of spatial changes in campsite use.

\section{Forest cover}

Sustainable recreation management requires the ability to maintain good resource conditions on recreation sites and campsites over time (Marion \& Sober 1987). Our data documented a substantial reduction in forest cover on campsites over the 32-year period. Previous studies show that onsite tree mortality rates greatly exceed off-site rates and that successful tree regeneration on campsites is rare (Cole 1986; Marion \& Merriam 1985a; Smith \& Newsome 2002). Our findings mirror these. Comparison of campsite/control data on tree density, cover, and recruitment over 32 years characterize a significant reduction in tree loss, canopy cover, and seedlings on campsites. We anticipate that this trend will continue in absence of effective management actions, resulting in the loss of all campsite trees, followed by those in adjacent off-site areas. Our data revealed that 21 additional campsites have lost their canopy cover in 2014 than in 1982.

Loss of trees due to malicious damage and firewood cutting are entirely "avoidable" recreation impacts (Marion 2014). The BWCAW has had an excellent Leave No Trace education program since the 1970's that asks campers to use small-diameter dead and downed firewood. Our data indicate that this program has been insufficiently effective in addressing low impact firewood gathering practices. Tree-felling is caused largely by the need for firewood so prohibiting campfires has been an increasingly common U.S. management response. However, Reid and Marion (2005) evaluated campfire-related impacts and polices in seven protected areas, finding that fire bans did not substantially reduce tree damage and cutting due to continued illegal campfire activity. Prohibitions on axes, hatchets, and saws were identified as a more effective response.

Visitor use management frameworks direct managers to define "desired resource conditions" and for campsites this should address the acceptability of tree-less campsites in forested settings (Marion 2016). A substantial limitation of most campsite monitoring programs conducted to provide data for visitor use management decision-making is that they generally do not assess tree numbers, densities, or cover (Cole et al. 2008; Cole 2013). This study illustrates the need for incorporating such measures into these systems, and for long-term studies that evaluate a more comprehensive array of ecological measurements. Rapid assessment ratings-based monitoring programs are more likely to miss documenting potentially important long-term ecological changes on campsites and recreation sites.

\section{Groundcover and soil}


The substantial reductions in campsite tree cover allow shade-intolerant plants like resistant graminoids, to replace shade-tolerant plants, like broad-leafed herbs. These compositional changes are contributing to greater campsite sustainability, as research shows that graminoids are substantially more tramplingresistant and able to colonize peripheral campsite areas, reducing soil loss (Cole 1995a; Cole 1995b; Marion et al. 2016; Sun \& Liddle 1993). Graminoids also have greater resilience to trampling, recovering more quickly due to their flexible stems, narrow durable leaves, and fast growth rates (Pickering 2010; Sun \& Liddle 1993). However, as campsites develop a grassy "lawn-like" appearance these changes are unnatural both ecologically and aesthetically; visitors may no longer perceive that they are camping within a pristine wilderness setting.

Our data reveal that substantial soil loss has occurred on campsites. Shoreline boat landing areas have the deepest incision and the most localized soil loss. While less soil loss occurs across core campsite areas, aggregate soil loss is substantial due to the larger areas affected. We were unable to locate other studies that had estimated or measured soil loss on campsites. As sites continue to erode, there will be more exposed rock and roots that will encourage visitors to shift tenting to adjacent offsite satellite areas. Though we lack comparative data from 1982, we expect that soil loss occurs on campsites at a fairly low but steady rate over time. Soil loss is the most significant and irreversible long-term change occurring on BWCAW campsites. It is also a cumulative change - soil eroded by wind or water does not return unless replaced through site management actions.

Only two campsite impact indicators were significantly influenced by level of use: soil loss and the percentage of trees with exposed roots, which also reflects soil loss. Other studies have found that high levels of use contribute to higher impacts, including reduced vegetation cover, greater soil loss, and larger campsite sizes (Cole 1993; Monz et al. 2013). In the BWCAW, campsites do receive a wide range of use but visitation has been relatively stable, so impacts such as campsite size and vegetation cover tend to reach an equilibrium over time (Cole et al. 2008). As campsite trees continue to be removed and graminoid cover expands we expect the rate of soil loss to decline. Given our findings, we stress that reducing campsite use in an effort to reduce environmental degradation would be an ineffective policy.

\section{Conclusion}

To preserve protected natural areas in perpetuity while providing recreation opportunities, managers need to consider potential impacts over not one year or ten years, but over decades and centuries. The results of this study document long-term ecological changes and trends in resource conditions on a large sample of wilderness campsites. Campsite conditions over 32 years have changed significantly. While the aggregate area of campsite impact has remained similar, expansion into peripheral areas has occurred while core areas have contracted. The area of exposed soil has increased, substantial numbers of trees have been lost, dramatic changes in plant composition have occurred, and campsites have lost substantial amounts of soil. Results from this study quantify these long-term changes and suggest effective sustainable management prescriptions for the BWCAW that are also applicable to protected areas internationally.

By focusing greater attention on sustainable campsite management, agency staff can prolong the ability of campsites to accommodate visitation and remain in good condition. We suggest that this involve a combination of actions that include: 1) selecting resistant locations that hinder site expansion, 2) 
construction of side-hill campsites that attract and spatially concentrate use and impact, 3) maintenance of sites to reduce soil loss, and 4) education and regulation of visitors to promote use of low impact camping practices. We note that agency funding and staffing constraints often limit the ability of field staff to accomplish these tasks. However, we emphasize that intensive visitor use will demand intensive site and visitor management if protected area managers are to accomplish their dual mission of preserving naturally functioning ecosystems while accommodating ample opportunities for high quality recreational visits.

\section{Acknowledgements}

This study was funded by the USDI U.S. Geological Survey and the USDA Forest Service, Superior National Forest. The authors would like to thank field assistants Claire Underwood and Jeff Feldhaus for their dedicated work and USFS BWCAW staff Ann Schwaller and Steve Cochran for their administrative and logistical assistance.

\section{Appendix A. Managing for Sustainability}

This Appendix is included to provide an extended presentation of our findings and their implications for improving sustainable camping management in the BWCAW and other protected natural areas internationally. This section addresses research question 3) What are the implications of these findings for improving the sustainability of campsite management? These findings, implications, and "Best Management Practice" guidance are presented as five key visitor impact management strategies that protected area managers can consider for avoiding and minimizing environmental impacts on both campsites and recreation sites. See Hammitt et al. (2014), Leung \& Marion (2004), and Marion (2003, 2016), and Reid \& Marion (2004) for additional guidance.

Manage Use Levels. Numerous recreation ecology studies have reported a curvilinear use-impact relationship whereby the majority of impact occurs between campsite creation and moderate levels of use (20-40 nights/yr) (Hammitt et al. 2014; Marion 2016; Marion et al. 2016). For moderate use campsites, a doubling or tripling of use contributes little additional impact because many indicators have already reached high or near-maximum impact levels. For example, organic soils and tree seedlings/saplings have already been lost and soil compaction is at near-maximum levels (Marion and Merriam 1985a). Reducing use to address campsite impacts would be ineffectual unless substantial use reductions were applied to achieve extremely low use levels (Kangas et al. 2007; Marion et al. 2016; Monz et al. 2013).

Modify the Location of Use. A key objective for managing campsites sustainably is to ensure that the mean and aggregate area of impact does not increase over time (Marion 2003; Marion 2016). Selecting and designating impact-resistant campsites limits campsite creation visitors and allows use of locations that inhibit site expansion. We tested the predictive efficacy of a site expansion potential rating that could be used to select sustainable campsite locations (Table 2). This four-class rating was designed to favor campsites whose expansion would be constrained by sloping topography, rockiness, wet soils, or dense woody vegetation. Our findings were promising but non-significant. In the field, we observed that the presence and density of woody vegetation cover as a deterrent to campsite expansion was ephemeral, given that forest succession, wildfires, insects/diseases, wind-throw, and tree cutting by visitors can remove trees and shrubs over time (Figure 4). Further, we noted that satellite tenting areas were created 
even when only a quarter of the adjacent offsite areas were favorable to expansion. Based on these findings we refined the expansion potential rating as:

A sustainable campsite should stay its designed size in perpetuity, bounded by adjacent offsite areas that are not conducive to tenting or other camping activities due to sloping topography $(>20 \%)$ or substantial rockiness. Assess the percentage of adjacent offsite areas within a $30 \mathrm{~m}$ buffer around a proposed campsite boundary that would inhibit all tenting activity. Optimal campsite locations should score above $85 \%$.

When optimal naturally-occurring locations are unavailable, managers can also construct expansionresistant "side-hill" campsites in sloping terrain (>20\%) (Marion 2016). Similar to side-hill trails, cutand-fill excavation is employed to construct separate tent pads and a core cooking area (Marion \& Farrell 2002). Hundreds of side-hill campsites have been constructed along the U.S. Appalachian Trail and research reveals them to be effective in spatially concentrating camping activity to a small "footprint" of impact, and able to resolve many social problems (Daniels \& Marion 2006).
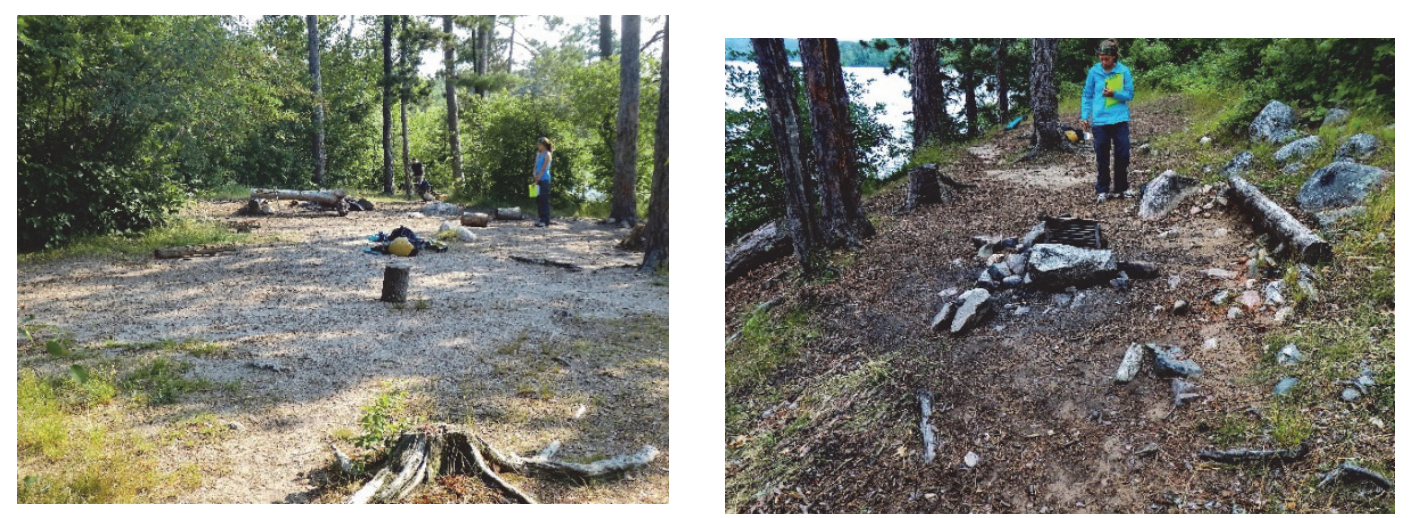

Figure 4. Dense woody vegetation is not a long-term deterrent to campsite expansion in flat terrain (left). Selecting or constructing campsites in sloping terrain (right) spatially concentrates camping activities on a small "footprint" of disturbance.

Increase Resource Resistance. Campsite layout and design attributes can be altered to improve campsite sustainability (Marion 2003; Marion 2016). We suggest using visitor interviews or surveys to inform the design of campsites that meet visitor's needs while spatially concentrating camping activities such as tenting, cooking, eating, and campfires. This study revealed that visitors will readily create new use areas outside of campsite boundaries when their needs are not being met. Their motives must be known to effectively resolve this problem: are they searching for privacy or natural quiet, smooth well-drained tent sites, shade, or some combination?

Managers can shrink campsite sizes through a variety of site management actions, several of which were pioneered in the BWCAW. First, managers can visually identify, improve, or provide facilities for 
common camping activities (Marion \& Sober 1987). For example, a steel fire ring can be anchored in a resistant spot (e.g., on bedrock) so that visitors consistently use a single fire site (Reid \& Marion 2005). A sufficient number of smooth well-drained tenting sites can be created and maintained. Both actions have been commonly applied and were observed to be effective on BWCAW campsites. Second, to prevent use of undesirable areas, agency staff can bury large rocks deeply with a protruding portion that prevents tenting (Marion \& Sober 1987). If such "ice-berg" rocks are unavailable, managers can create uneven terrain by digging shallow depressions and mounding soil to ruin tenting spots, along with adding organic litter and plantings to naturalize the area.

Third, our findings revealed that shoreline boat landing areas were particularly prone to substantial soil loss. Selecting a single resistant boat landing and closing/restoring additional landings can reduce unnecessary impact to vegetation and soils. When necessary, landings can be "hardened" against traffic and wave action with subtle naturally-appearing rockwork to limit soil loss. And fourth, soil loss can be limited by increasing ground vegetation cover. An implication from this study is that managers could select campsites with open canopies or non-forested locations where resistant graminoid cover will likely persist in less trafficked campsite areas. Or seeding with native grasses could help expand campsite plant cover. On forested sites, managers could plant seedlings of native trees and shrubs in the most protected locations, selecting species that create the least shade.

Modify Visitor Behavior. The U.S. Leave No Trace educational program is widely applied in U.S. and many international protected natural areas to convey and encourage the adoption of low impact outdoor practices (Marion 2014). For example, a long-term BWCAW educational program asks visitors to use camp stoves for cooking, and when a campfire is desired, to collect only small diameter dead wood found lying on the ground. A regulation prohibits cutting live vegetation. Our findings reveal that both actions are insufficient in deterring a substantial amount of tree cutting; we counted 1438 tree stumps on or near 81 campsites in 2014. An enhanced and expanded educational messaging program focused on this impact could be effective, though explicitly requesting or requiring visitors to leave all woods tools (axe, hatchet, saw) at home should also be considered (Marion \& Reid 2007).

Close and Rehabilitate the Resource. Closing highly impacted campsites and replacing them with new sites is an effective strategy only when: 1) the new sites are considerably more impact-resistant than the closed sites, and 2) continued use of the closed sites can be effectively prevented (Cole \& Ranz 1983; Reid \& Marion 2004). Campsite closure is easiest when camping is restricted to designated campsites; extracting site facilities effectively communicates that the campsite is no longer legal to use. In 2014 we relocated and surveyed 12 campsites that had been closed between 31-45 years. Recovery was complete on four campsites (indistinguishable from the surrounding forest), substantial on five campsites, and incomplete on portions of three sites that were receiving day use activity as lunch stops.

Campsite closure in areas that don't employ designated site camping is more challenging (Reid \& Marion 2004). At BWCAW we observed that felling large trees across undesired portions of open sites and closed sites has been an effective management practice. Plantings of tree seedlings on closed sites were also observed to have high survivorship. Other effective practices include the previously described tenting site ruination work and encircling the closed site with cord and site closure signs (Marion 2003; 2016; Reid \& Marion 2004). 


\section{References}

Cole, D., \& Ranz, B. (1983). Temporary campsite closures in the Selway-Bitterroot Wilderness. Journal of Forestry, 81(11), 729-732.

Cole, D. (1986). Ecological changes on campsites in the Eagle Cap Wilderness, 1974 to 1984. USDA Forest Service Research Paper INT-368. 15pp.

Cole, D. (1992). Modeling Wilderness Campsites: Factors that Influence Amount of Impact. Environmental Management, 16(2), 255-264.

Cole, D. (1993). Trampling Effects on Mountain Vegetation in Washington, Colorado, New Hampshire, and North Carolina. Research Paper INT-464. Ogden, UT: USDA Forest Service, Intermountain Research Station. 56pp.

Cole, D. (1995a). Experimental trampling of vegetation. I. Relationship between trampling intensity and vegetation response. Journal of Applied Ecology, 32, 203-214.

Cole, D. (1995b). Experimental trampling of vegetation. II. Predictors of resistance and resilience. Journal of Applied Ecology, 32, 215-224.

Cole, D., Foti, P. \& Brown, M. (2008). Twenty years of change on campsites in the backcountry of Grand Canyon National Park. Environmental Management, 41, 959-970.

Cole, D. (2013). Changing conditions on wilderness campsites: Seven case studies of trends over 13 to 32 years. USDA For. Serv. Gen. Tech. Rep. RMRS-GTR-300. 99 p.

Cole, D., \& Parsons, D. (2013). Campsite impact in the wilderness of Sequoia and Kings Canyon National Parks: Thirty years of change. USDI Nat. Park Serv. Nat. Res. Tech. Rpt. NPS/SEKI/NRTR-2013/665.

Daniels, M. \& Marion, J. (2006). Visitor evaluations of management actions at a highly impacted Appalachian Trail camping area. Environmental Management, 38(6), 1006-1019.

Frissell, S. \& Duncan, D. (1965). Campsite preference and deterioration in the Quetico-Superior Canoe Country. Journal of Forestry, 63(4), 256-260.

Growcock, A., \& Pickering, C. (2011). A guilt-free roll in the grass: minimal short-term impacts from short-term camping in the Australian Alps. Journal of Ecotourism, 10(1), 86-100.

Hall, T., \& Farrell, T. (2001). Fuelwood depletion at wilderness campsites: extent and potential ecological significance. Environmental Conservation, 28, 1-7.

Hammitt, W., Cole, D. \& Monz, C. (2014). Wildland Recreation: Ecology and Management. $3^{\text {rd }}$ Ed. John Wiley and Sons, New York.

Kangas, K., Sulkava, P., Koivuniemi, P., Tolvanen, A., Siikamaki, P., \& Norokorpi, Y. (2007). What determines the area of impact around campsites? A case study in a Finnish national park. Forest Snow and Landscape Research, 81(1-2), 139-150.

Leung, Y. \& Marion, J. (1999). Spatial strategies for managing visitor impacts in National Parks. Journal of Park and Recreation Administration, 17(4), 20-38.

Leung, Y. \& Marion, J. (2004). Managing Impacts of Camping. In: R. Buckley (ed.), Environmental Impact of Tourism (pp. 245-258). Cambridge, MA: CABI Publishing. 
Leverington, F., Costa, K., Pavese, H., Lisle, A., \& Hockings, M. (2010). A global analysis of protected area management effectiveness. Environmental Management, 46(5), 685-698.

Marion, J. (1984). Ecological changes resulting from recreational use: A study of backcountry campsites in the Boundary Waters Canoe Area Wilderness, Minnesota. University of Minnesota, Department of Forest Resources. Ph.D. Dissertation. 279 pp.

Marion, J. \& Merriam, L. (1985a). Recreational impacts on well-established campsites in the Boundary Waters Canoe Area Wilderness. University of Minnesota, Agricultural Experiment Station, Technical Bulletin AD SB 2502, St. Paul, MN.

Marion, J. \& Merriam, L. (1985b). Predictability of recreational impact on soils. Soil Science Society of America Journal, 49(3), 751-753.

Marion, J. \& Sober, T. (1987). Environmental impact management in the Boundary Waters Canoe Area Wilderness. Northern Journal of Applied Forestry, 4(1), 7-10.

Marion, J., \& Cole, D. (1996). Spatial and temporal variation in soil and vegetation impacts on campsites: Delaware Water Gap National Recreation Area. Ecological Applications 6(2), 520530.

Marion J., \& Farrell, T. (2002). Management practices that concentrate visitor activities: Camping impact management Isle Royale National Park, USA. Journal of Environmental Management, $66,201-212$.

Marion, J. (2003). Camping impact management on the Appalachian National Scenic Trail. Appendix 2, Camping Management Practices. Report published by the Appalachian Trail Conference, Harper's Ferry, WV. 109 pp.

Marion, J. (2014). Leave No Trace in the outdoors. Stackpole Books. 128pp.

Marion, J. (2016). A review and synthesis of recreation ecology research supporting carrying capacity and visitor use management decision-making. Journal of Forestry, 114 (3), 339-351.

Marion, J., Leung, Y., Eagleston, H. \& Burroughs, K. (2016). A Review and Synthesis of Recreation Ecology Findings on Visitor Impacts to Wilderness and Protected Natural Areas. Journal of Forestry, 114 (2), 352-362.

McCool, S., Merriam, L., \& Cushwa, C. (1969). The condition of wilderness campsites in the Boundary Waters Canoe Area. Minnesota Forestry Research Notes 202, School of Forestry, University of Minnesota, 4pp.

Merriam, L., Smith, C., Miller, D., Huang, C., Tappeiner, J., Goeckermann, K., Bloemendal, J., \& Costello, T. (1973). Newly developed campsites in the Boundary Waters Canoe Area: A study of 5 year's use. St. Paul, MN: University of Minnesota, Agricultural Experiment Station, Bulletin $511,27 \mathrm{p}$.

Merriam, L. \& Smith, C. (1974). Visitor impact on newly developed campsites in the Boundary Waters Canoe Area. Journal of Forestry, 72, 627-630.

Merriam, L. \& Peterson, R. (1983). Impact of 15 years of use on some campsites in the Boundary Waters Canoe Area. Minneapolis, MN: University of Minnesota Note No. 282. Minnesota Forestry Research Notes. 
Monti, P., \& Mackintosh, E. (1979). Effect of camping on surface soil properties in the boreal forest region of northwestern Ontario, Canada. Soil Science Society of America Journal, 43, 10241029.

Monz, C., Pickering, C. \& Hadwen, W. (2013). Recent advances in recreation ecology and the implications of different relationships between recreation use and ecological impacts. Frontiers in Ecology and the Environment, 11(8), 441-446.

Moyle, J., \& Moyle, E. (1977). Northland wildflowers: the comprehensive guide to the Minnesota region. University of Minnesota Press, Minneapolis.

Pickering, C. (2010). Ten factors that affect the severity of environmental impacts of visitors in protected areas. Ambio, 39(1), 70-77.

Prettyman, D. (1987). Soil survey of Kawishiwi area, Minnesota: parts of Lake and Cook Counties in Superior National Forest. U.S. Department of Agriculture Soil Conservation Service, Washington, D.C.

Reid, S. \& Marion, J. (2004). Effectiveness of a confinement strategy for reducing campsite impacts in Shenandoah National Park. Environmental Conservation, 4, 1-9.

Reid, S. \& Marion, J. (2005). A comparison of campfire impacts and policies in seven protected areas. Environmental Management, 36(1), 48-58.

Smith, A., \& Newsome, D. (2002). An integrated approach to assessing, managing and monitoring campsite impacts in Warren National Park, Western Australia. Journal of Sustainable Tourism, 10(4), 343-359.

Sun, D., \& Liddle, M. (1993). Trampling resistance, stem flexibility and leaf strength in nine Australian grasses and herbs. Biological Conservation, 65(1), 35-41. 